\title{
Redescription of Two Urostylid Ciliates (Ciliophora: Urostylida), Anteholosticha pulchra and Metaurostylopsis struederkypkeae from Korea
}

\author{
Kyung-Min Park, Jae-Ho Jung, Gi-Sik Min* \\ Department of Biological Sciences, Inha University, Incheon 402-751, Korea
}

\begin{abstract}
Two urostylid ciliates, Anteholosticha pulchra (Kahl, 1932) Berger, 2003 and Metaurostylopsis struederkypkeae Shao et al., 2008, new to Korea, were collected from the Yellow Sea and the East Sea, Korea, respectively. They were identified based on live observation and protargol impregnation. Taxonomical characters of A. pulchra are as follows: $190-300 \times 30-55 \mu \mathrm{m}$ size in vivo; contractile vacuole located on the left side of the posterior 1/4 of the cell; spherical-reddish granules at cirral bases and around dorsal bristles, somewhat sparsely distributed throughout the cell surface; four frontal and two frontoterminal cirri; four dorsal kineties; caudal cirri absent. Metaurostylopsis struederkypkeae is characterized as follows: $80-110 \times 40-50 \mu \mathrm{m}$ size in vivo; caudal cirri absent; two types of cortical granules: type 1, yellow-green arranged along the ventral cirral rows and dorsal kineties; type 2, small and reddish, with an irregular arrangement; four frontal, four to eight frontoterminal, and two to six transverse cirri; five to seven left and three to five right marginal rows. Sequences of small subunit ribosomal DNA were determined from both species, and pairwise distances with their relatives were analyzed.
\end{abstract}

Keywords: Anteholosticha pulchra, Metaurostylopsis struederkypkeae, urostylid ciliate, marine, Korea

\section{INTRODUCTION}

Genera Anteholosticha Berger, 2003 and Metaurostylopsis Song et al., 2001 belong to the family Urostylidae Bütschli, 1889. This family is characterized by having one or more marginal rows of left and right marginal cirri and the midventral cirri which arranged as a "zig-zag" file (Borror, 1979; Borror and Wicklow, 1983; Lynn, 2008).

Diverse and polyphyletic species in the Holosticha complex (Gao et al., 2010) were split up into four genera, Holosticha, Anteholosticha, Caudiholosticha and Biholosticha by Berger (2003). Recently Li et al. (2009) added another genus Nothoholosticha to this complex, and therefore there are five genera in the Holosticha complex at present. The genus Anteholosticha can be distinguished from other genera in Holosticha complex by its lack of caudal cirri and several other apomorphic characters, e.g., anterior end of left marginal row curved rightwards, proximalmost membranelles widened (Berger, 2003). Recently a Chinese population of A. pulchra was reported by Li et al. (2007).

The genus Metaurostylopsis was established by Song et al. (2001). The characteristics of this genus are as follows: clearly differentiated frontal, buccal, transverse cirri and frontoterminal cirral row present; caudal cirri absent; more than one left and right marginal row (Song et al., 2001). Metaurostylopsis struederkypkeae was newly established by Shao et al. (2008).

Here, we redescribe two urostylid ciliates, A. pulchra and M. struederkypkeae, collected from Korea. For precise identification and description, we conducted live observation, protargol impregnation and small subunit ribosomal DNA (SSU rDNA) sequence analysis.

\section{MATERIALS AND METHODS}

Anteholosticha pulchra was isolated from Incheon Harbor (salinity, $30.6 \%$; temperature, $-0.6^{\circ} \mathrm{C} ; 37^{\circ} 26^{\prime} \mathrm{N}, 126^{\circ} 35^{\prime} \mathrm{E}$ ),

\footnotetext{
(c) This is an Open Access article distributed under the terms of the Creative Commons Attribution Non-Commercial License (http://creativecommons.org/ licenses/by-nc/3.0/) which permits unrestricted non-commercial use, distribution, and reproduction in any medium, provided the original work is properly cited. pISSN 2234-6953
}

*To whom correspondence should be addressed

Tel: 82-32-860-7692, Fax: 82-32-874-6737

E-mail: mingisik@inha.ac.kr 
Incheon, Korea at January of 2011. Metaurostylopsis struederkypkeae was collected from the lagoon of Youngrang (salinity, $14.8 \%$; temperature, $18.3^{\circ} \mathrm{C} ; 38^{\circ} 13^{\prime} \mathrm{N}, 128^{\circ} 35^{\prime} \mathrm{E}$ ), Sokcho, Korea at June of 2011. These two populations were maintained in petri dishes with rice grains to enrich bacteria growth as a food resource. The specimens were observed in vivo under a light microscope (Leica DM2500, Wetzlar, Germany) at a magnification of $50 \times$ to $1,000 \times$. Protargol impregnation was performed to reveal the infraciliatures (Foissner, 1991). Drawing was performed under a light microscope at a magnification of $1,000 \times$. Terminology and classification were mainly followed according to Lynn (2008).

DNA extraction, amplification and sequencing of nearly complete SSU rDNA were performed according to Jung et al. (2011). Our sequences and retrieved sequences from GenBank were aligned using BioEdit (Hall, 1999), and pairwise genetic distance based on Kimura two-parameter inference was obtained using MEGA 4.0 (Kumar et al., 2004).

\section{RESULTS}

Phylum Ciliophora Doflein, 1901

Class Spirotrichea Bütschli, 1889

Order Urostylida Jankowski, 1979

Family Urostylidae Bütschli, 1889

Genus Anteholosticha Berger, 2003

1*Anteholosticha pulchra (Kahl, 1932) Berger, 2003

(Table 1, Figs. 1A-E, 2)

Keronopsis pulchra Kahl, 1932: 573, fig. 104; Kahl, 1933: 109, fig. 16.

Holosticha (Keronopsis) pulchra: Berger, 2001: 36.

Anteholosticha pulchra: Berger, 2003: 377; Berger, 2006: 435, fig. 90; Li et al., 2007: 113, figs. 4-7.

Description. Live cell size usually $190-300 \times 30-55 \mu \mathrm{m}$, slender in shape (Figs. 1A, 2A, B), flexible but not contractile, anterior and posterior ends rounded, contractile vacuole approxi-

Table 1. Comparison of morphometric data from Anteholosticha pulchra with Li et al. (2007)

\begin{tabular}{|c|c|c|c|c|c|c|c|}
\hline & $\mathrm{P}$ & Min & Max & Mean & SD & CV & $\mathrm{n}$ \\
\hline \multirow[t]{2}{*}{ Length of body $(\mu \mathrm{m})$} & Ko & 150 & 220 & 184.9 & 16.9 & 9.1 & 21 \\
\hline & $\mathrm{Ch}$ & 172 & 352 & 250.0 & 45.1 & 18.0 & 25 \\
\hline \multirow[t]{2}{*}{ Width of body $(\mu \mathrm{m})$} & Ko & 37.5 & 57.5 & 48.7 & 5.6 & 11.6 & 21 \\
\hline & $\mathrm{Ch}$ & 48 & 100 & 74.8 & 12.5 & 16.7 & 25 \\
\hline \multirow[t]{2}{*}{ Length of buccal field $(\mu \mathrm{m})$} & Ko & 45 & 57.5 & 51.1 & 3.8 & 7.4 & 21 \\
\hline & $\mathrm{Ch}$ & 46 & 100 & 70.1 & 10.0 & 14.3 & 25 \\
\hline \multirow[t]{2}{*}{ No. of membranelles } & Ko & 46 & 60 & 51 & 3.6 & 7.1 & 21 \\
\hline & $\mathrm{Ch}$ & 38 & 57 & 47.7 & 4.2 & 8.8 & 25 \\
\hline \multirow[t]{2}{*}{ No. of buccal cirri } & Ko & 1 & 1 & 1 & 0 & 0 & 21 \\
\hline & $\mathrm{Ch}$ & 1 & 1 & 1 & 0 & 0 & 25 \\
\hline \multirow[t]{2}{*}{ No. of frontal cirri } & Ko & 4 & 4 & 4 & 0 & 0 & 21 \\
\hline & $\mathrm{Ch}$ & 4 & 4 & 4 & 0 & 0 & 25 \\
\hline \multirow[t]{2}{*}{ No. of transverse cirri } & Ko & 7 & 9 & 7.8 & 0.7 & 9.6 & 21 \\
\hline & $\mathrm{Ch}$ & 5 & 8 & 6.4 & 0.7 & 10.9 & 25 \\
\hline \multirow[t]{2}{*}{ No. of frontoterminal cirri } & Ko & 2 & 2 & 2 & 0 & 0 & 21 \\
\hline & $\mathrm{Ch}$ & 2 & 2 & 2 & 0 & 0 & 25 \\
\hline \multirow[t]{2}{*}{ No. of pairs of midventral cirri } & Ko & 27 & 34 & 32 & 2.1 & 6.5 & 21 \\
\hline & $\mathrm{Ch}$ & 21 & 38 & 28.4 & 4.9 & 17.3 & 25 \\
\hline \multirow[t]{2}{*}{ No. of left marginal row } & Ko & 51 & 68 & 56.1 & 4.1 & 7.3 & 21 \\
\hline & $\mathrm{Ch}$ & 40 & 70 & 52.8 & 8.2 & 15.5 & 25 \\
\hline \multirow[t]{2}{*}{ No. of right marginal row } & Ko & 54 & 73 & 61.6 & 4.3 & 7.0 & 21 \\
\hline & $\mathrm{Ch}$ & 49 & 75 & 60.3 & 7.9 & 13.1 & 25 \\
\hline \multirow[t]{2}{*}{ No. of macronuclear nodules } & Ko & 38 & 71 & 49.1 & 7.4 & 15.1 & 21 \\
\hline & $\mathrm{Ch}$ & 31 & 47 & 40.9 & 4.8 & 11.7 & 8 \\
\hline \multirow[t]{2}{*}{ No. of dorsal kineties } & Ko & 4 & 4 & 4 & 0 & 0 & 21 \\
\hline & $\mathrm{Ch}$ & 4 & 4 & 4 & 0 & 0 & 25 \\
\hline
\end{tabular}

All data compared protargol-impregnated specimens of Korean population (Ko) and Chinese population (Ch).

Frontal cirri including parabuccal cirrus (III/2)

$\mathrm{P}$, population; Min, minimum; Max, maximum; Mean, arithmetic mean; $\mathrm{CV}$, coefficient of variation in $\%$; $\mathrm{n}$, number of individuals examined.

Korean name: ${ }^{1 *}$ 홍색옛전열하모충 (신칭) 


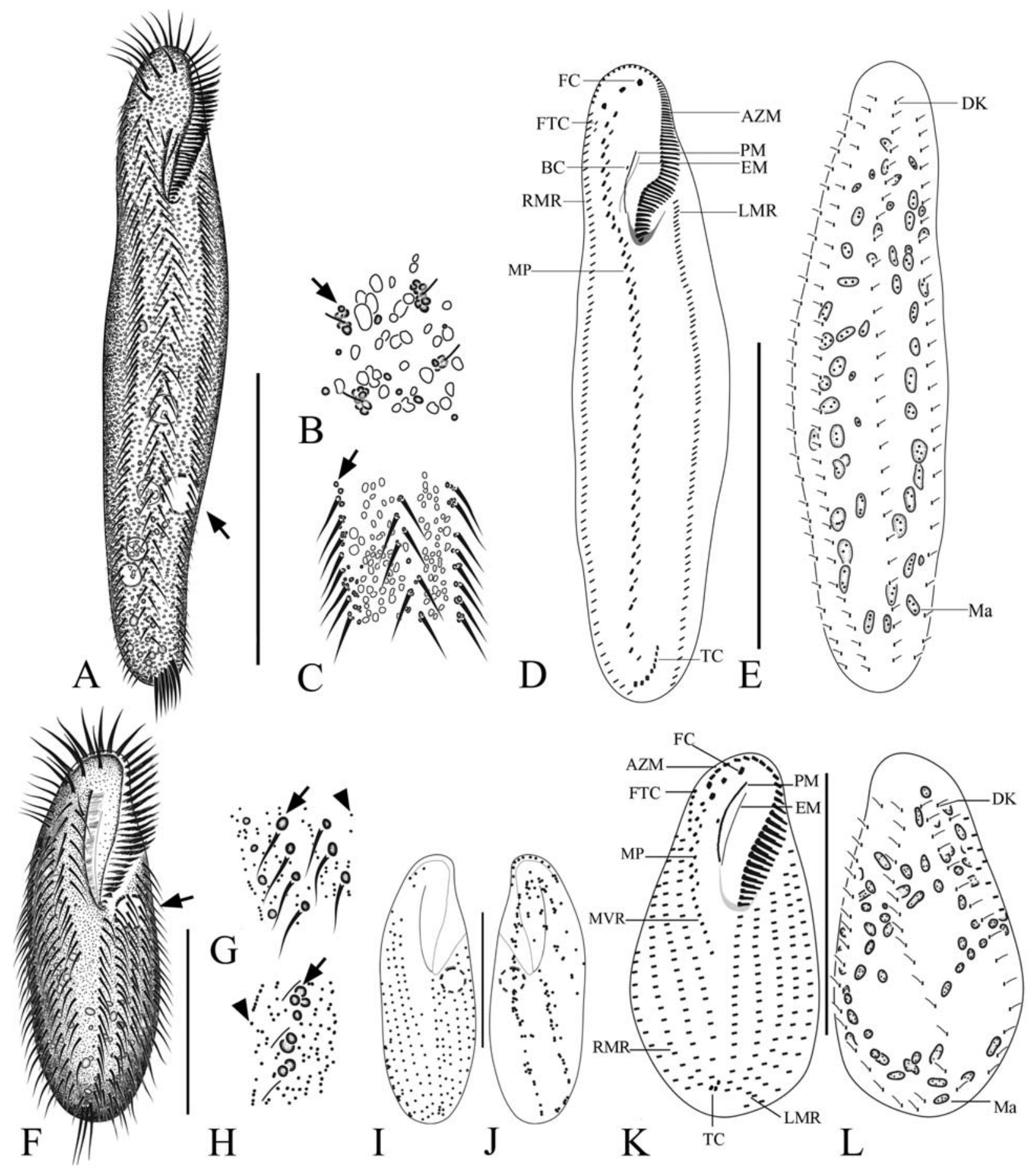

Fig. 1. Morphology of Anteholosticha pulchra and Metaurostylopsis struederkypkeae from live (A-C, F-J) and protargol impregnated (D, E, K, L) specimens. A-E, Anteholosticha pulchra: A, Ventral view of live, contractile vacuole (arrow); B, C, Pattern of cortical granules in dorsal and ventral views, reddish cortical granules (arrow); D, E, Cirral base in ventral and dorsal views from protargol impregnation; F-L, Metaurostylopsis struederkypkeae: F, Ventral view of live, contractile vacuole (arrow); G, H, Ventral and dorsal views, yellow-green cortical granules (arrow), small reddish cortical granules (arrowhead); I, J, Ventral and dorsal views which show the arrangement of yellow-green cortical granules; K, L, Cirral base on ventral and dorsal views with protargol impregnation. AZM, adoral zone of membranelles; BC, buccal cirrus; DK, dorsal kineties; EM, endoral membrane; FC, frontal cirri; FTC, frontoterminal cirri; LMR, left marginal row; Ma, macronuclear nodules; MP, midventral pairs; MVR, midventral row; PM, paroral membrane; RMR, right marginal row; TC, transverse cirri. Scale bars: $A-E=100 \mu \mathrm{m}, \mathrm{F}-\mathrm{L}=50 \mu \mathrm{m}$. 

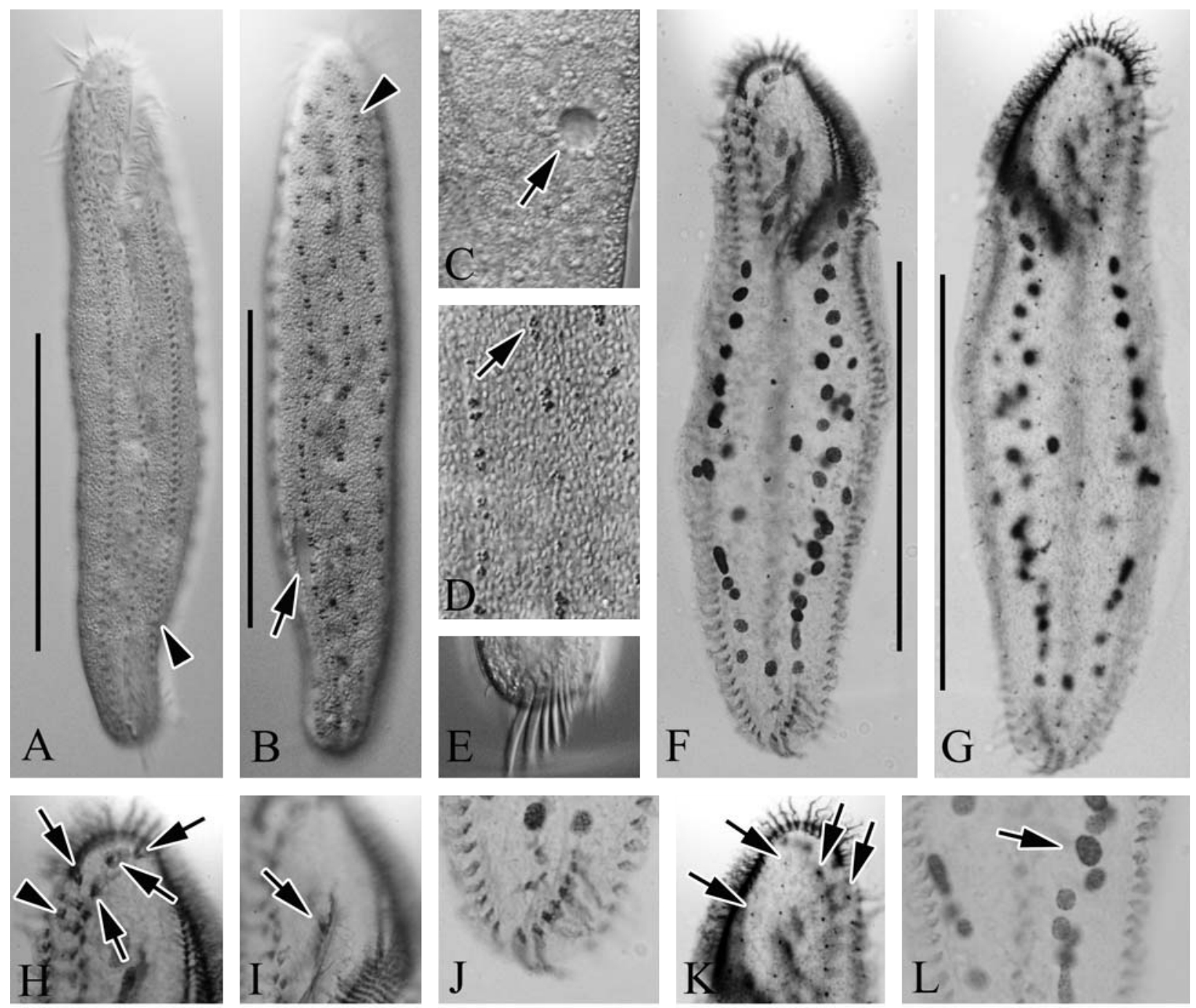

Fig. 2. Micrographs of Anteholosticha pulchra from live (A-E) and protargol impregnated (F-L) specimens. $A$, $B$, Live ventral (A) and dorsal (B) view, arrangement of cortical granules (arrowhead); C, Ventral view, contractile vacuole (arrow); D, Dorsal view, reddish cortical granules (arrow); E, Live ventral view of transverse cirri; F, G, Dorsal and ventral views of protargol-impregnated specimen; $\mathrm{H}$, Ventral view, the frontal (arrows) and frontoterminal (arrowhead) cirri; I, Buccal cirri (arrow); J, Ventral view, the transverse cirri; K, Dorsal view, the dorsal kineties, typically four; L, Macronuclear nodules (arrow). Scale bars: A, B, F, G=100 $\mu \mathrm{m}$.

mately $10 \mu \mathrm{m}$ in diameter, positioned on left side of posterior $1 / 4$ of cell (Figs. 1A, 2B, C, arrow). Spherical-reddish cortical granules at cirral bases and around dorsal bristles, $c a .1$ $\mu \mathrm{m}$ across, some sparsely distributed throughout cell surface (Figs. 1B, C, 2D, arrow). Four frontal cirri each located in anterior ventral area, $c a .18 \mu \mathrm{m}$ (Fig. $2 \mathrm{H}$, arrows), and two frontoterminal located near anterior end of right marginal row (Fig. $2 \mathrm{H}$, arrowhead) and seven to nine transverse cirri (Fig. 2E, J), respectively $c a .10$ and $20 \mu \mathrm{m}$ in length, with one left and right marginal row located on left and right side (left marginal cirri $c a$. 56, right marginal cirri $c a$. 61). Buccal cirrus positioned near paroral membrane (Fig. 2I, arrow), cau- dal cirri absent. Four dorsal kineties extended from anterior to posterior area (Fig. 2G, K, arrows) and approximately 49 macronuclear nodules scattered in body (Figs. 1E, 2L).

46-60 membranelles in adoral zone, $c a$. 25-35\% of body length, and thick buccal lip. Long midventral pairs extending to transverse cirri, in a "zig-zag" pattern, 27-34 pairs of cirri. Food vacuoles colorless and sparsely located on cell.

Distribution. Germany (Kiel, the Baltic Sea), China (Laizhou, the Yellow Sea), and Korea (this study).

Remarks. Polyphyly of genus Anteholosticha was shown by molecular phylogenetic analysis based on the SSU rDNA. Therefore this genus should be divided into subgroups acc- 
Kyung-Min Park, Jae-Ho Jung, Gi-Sik Min

Table 2. Comparison of morphometric data from Metaurostylopsis struederkypkeae with Shao et al. (2008)

\begin{tabular}{|c|c|c|c|c|c|c|c|}
\hline & $P$ & Min & Max & Mean & SD & CV & $\mathrm{n}$ \\
\hline Length of body $(\mu \mathrm{m})$ & $\begin{array}{l}\text { Ko } \\
\text { Ch }\end{array}$ & $\begin{array}{l}65 \\
45\end{array}$ & $\begin{array}{l}98 \\
75\end{array}$ & $\begin{array}{l}82.7 \\
64.3\end{array}$ & $\begin{array}{r}11.17 \\
7.81\end{array}$ & $\begin{array}{l}13.5 \\
12.1\end{array}$ & $\begin{array}{l}16 \\
20\end{array}$ \\
\hline Width of body $(\mu \mathrm{m})$ & $\begin{array}{l}\text { Ko } \\
\text { Ch }\end{array}$ & $\begin{array}{l}25 \\
18\end{array}$ & $\begin{array}{l}56 \\
36\end{array}$ & $\begin{array}{l}35.2 \\
25.8\end{array}$ & $\begin{array}{l}7.41 \\
5.66\end{array}$ & $\begin{array}{l}21.0 \\
21.9\end{array}$ & $\begin{array}{l}16 \\
20\end{array}$ \\
\hline Length of buccal field ( $\mu \mathrm{m})$ & $\begin{array}{l}\text { Ko } \\
\text { Ch }\end{array}$ & $\begin{array}{l}25 \\
16\end{array}$ & $\begin{array}{l}43 \\
40\end{array}$ & $\begin{array}{l}33.7 \\
25.1\end{array}$ & $\begin{array}{l}4.85 \\
5.08\end{array}$ & $\begin{array}{l}14.4 \\
20.3\end{array}$ & $\begin{array}{l}16 \\
20\end{array}$ \\
\hline No. of membranelles & $\begin{array}{l}\text { Ko } \\
\text { Ch }\end{array}$ & $\begin{array}{l}25 \\
20\end{array}$ & $\begin{array}{l}36 \\
25\end{array}$ & $\begin{array}{l}30.8 \\
22.7\end{array}$ & $\begin{array}{l}3.27 \\
1.45\end{array}$ & $\begin{array}{r}10.6 \\
6.4\end{array}$ & $\begin{array}{l}16 \\
19\end{array}$ \\
\hline No. of frontal cirri & $\begin{array}{l}\text { Ko } \\
\text { Ch }\end{array}$ & $\begin{array}{l}4 \\
4\end{array}$ & $\begin{array}{l}4 \\
4\end{array}$ & $\begin{array}{l}4.0 \\
4.0\end{array}$ & $\begin{array}{l}0 \\
0\end{array}$ & $\begin{array}{l}0 \\
0\end{array}$ & $\begin{array}{l}16 \\
19\end{array}$ \\
\hline No. of frontoterminal cirri & $\begin{array}{l}\text { Ko } \\
\text { Ch }\end{array}$ & $\begin{array}{l}4 \\
4\end{array}$ & $\begin{array}{l}8 \\
6\end{array}$ & $\begin{array}{l}5.8 \\
4.6\end{array}$ & $\begin{array}{l}0.91 \\
0.69\end{array}$ & $\begin{array}{l}15.7 \\
15.1\end{array}$ & $\begin{array}{l}16 \\
19\end{array}$ \\
\hline No. of buccal cirri & $\begin{array}{l}\text { Ko } \\
\text { Ch }\end{array}$ & $\begin{array}{l}1 \\
1\end{array}$ & $\begin{array}{l}1 \\
1\end{array}$ & $\begin{array}{l}1.0 \\
1.0\end{array}$ & $\begin{array}{l}0 \\
0\end{array}$ & $\begin{array}{l}0 \\
0\end{array}$ & $\begin{array}{l}16 \\
20\end{array}$ \\
\hline No. of cirri in midventral pairs & $\begin{array}{l}\text { Ko } \\
\text { Ch }\end{array}$ & $\begin{array}{r}12 \\
8\end{array}$ & $\begin{array}{l}20 \\
14\end{array}$ & $\begin{array}{l}15.6 \\
10.6\end{array}$ & $\begin{array}{l}2.66 \\
1.66\end{array}$ & $\begin{array}{l}17.0 \\
15.7\end{array}$ & $\begin{array}{l}16 \\
18\end{array}$ \\
\hline No. of cirri in midventral row & $\begin{array}{l}\text { Ko } \\
\text { Ch }\end{array}$ & $\begin{array}{l}6 \\
4\end{array}$ & $\begin{array}{l}9 \\
8\end{array}$ & $\begin{array}{l}7.3 \\
5.4\end{array}$ & $\begin{array}{l}0.95 \\
1.25\end{array}$ & $\begin{array}{l}12.9 \\
22.9\end{array}$ & $\begin{array}{l}16 \\
18\end{array}$ \\
\hline No. of transverse cirri & $\begin{array}{l}\text { Ko } \\
\text { Ch }\end{array}$ & $\begin{array}{l}2 \\
2\end{array}$ & $\begin{array}{l}6 \\
5\end{array}$ & $\begin{array}{l}3.7 \\
3.2\end{array}$ & $\begin{array}{l}1.14 \\
0.75\end{array}$ & $\begin{array}{l}30.9 \\
23.3\end{array}$ & $\begin{array}{l}16 \\
17\end{array}$ \\
\hline No. of left marginal rows & $\begin{array}{l}\text { Ko } \\
\text { Ch }\end{array}$ & $\begin{array}{l}5 \\
4\end{array}$ & $\begin{array}{l}7 \\
5\end{array}$ & $\begin{array}{l}5.9 \\
4.1\end{array}$ & $\begin{array}{l}0.50 \\
0.32\end{array}$ & $\begin{array}{l}8.5 \\
7.7\end{array}$ & $\begin{array}{l}16 \\
19\end{array}$ \\
\hline No. of cirri in left marginal row 1 & $\begin{array}{l}\text { Ko } \\
\text { Ch }\end{array}$ & $\begin{array}{l}12 \\
10\end{array}$ & $\begin{array}{l}20 \\
16\end{array}$ & $\begin{array}{l}16.0 \\
11.7\end{array}$ & $\begin{array}{l}1.79 \\
1.88\end{array}$ & $\begin{array}{l}11.2 \\
16.0\end{array}$ & $\begin{array}{l}16 \\
19\end{array}$ \\
\hline No. of cirri in left marginal row 2 & $\begin{array}{l}\text { Ko } \\
\text { Ch }\end{array}$ & $\begin{array}{l}12 \\
11\end{array}$ & $\begin{array}{l}20 \\
17\end{array}$ & $\begin{array}{l}16.8 \\
13.8\end{array}$ & $\begin{array}{l}1.94 \\
1.80\end{array}$ & $\begin{array}{l}11.5 \\
13.0\end{array}$ & $\begin{array}{l}16 \\
19\end{array}$ \\
\hline No. of cirri in left marginal row 3 & $\begin{array}{l}\text { Ko } \\
\text { Ch }\end{array}$ & $\begin{array}{l}15 \\
12\end{array}$ & $\begin{array}{l}26 \\
19\end{array}$ & $\begin{array}{l}19.1 \\
15.6\end{array}$ & $\begin{array}{l}2.83 \\
2.22\end{array}$ & $\begin{array}{l}14.8 \\
14.2\end{array}$ & $\begin{array}{l}16 \\
19\end{array}$ \\
\hline No. of cirri in left marginal row 4 & $\begin{array}{l}\text { Ko } \\
\text { Ch }\end{array}$ & $\begin{array}{l}16 \\
13\end{array}$ & $\begin{array}{l}24 \\
22\end{array}$ & $\begin{array}{l}20.1 \\
16.3\end{array}$ & $\begin{array}{l}2.02 \\
2.29\end{array}$ & $\begin{array}{l}10.0 \\
14.0\end{array}$ & $\begin{array}{l}16 \\
19\end{array}$ \\
\hline No. of cirri in left marginal row 5 & $\begin{array}{l}\text { Ko } \\
\text { Ch }\end{array}$ & $\begin{array}{l}16 \\
11\end{array}$ & $\begin{array}{l}25 \\
16\end{array}$ & $\begin{array}{r}20.6 \\
-\end{array}$ & $\begin{array}{r}2.85 \\
-\end{array}$ & $\begin{array}{r}13.9 \\
-\end{array}$ & $\begin{array}{r}16 \\
2\end{array}$ \\
\hline No. of cirri in left marginal row 6 & $\begin{array}{l}\text { Ko } \\
\text { Ch }\end{array}$ & $\begin{array}{c}16 \\
-\end{array}$ & $\begin{array}{r}25 \\
-\end{array}$ & $\begin{array}{r}19.7 \\
-\end{array}$ & $\begin{array}{r}2.56 \\
-\end{array}$ & $\begin{array}{r}13.0 \\
-\end{array}$ & $\begin{array}{c}13 \\
-\end{array}$ \\
\hline No. of cirri in left marginal row 7 & $\begin{array}{l}\text { Ko } \\
\text { Ch }\end{array}$ & $\begin{array}{c}23 \\
-\end{array}$ & $\begin{array}{c}23 \\
-\end{array}$ & 23 & $\begin{array}{l}- \\
-\end{array}$ & - & $\begin{array}{l}1 \\
-\end{array}$ \\
\hline No. of right marginal rows & $\begin{array}{l}\text { Ko } \\
\text { Ch }\end{array}$ & $\begin{array}{l}3 \\
3\end{array}$ & $\begin{array}{l}5 \\
3\end{array}$ & $\begin{array}{l}4.1 \\
3.0\end{array}$ & $\begin{array}{l}0.50 \\
0\end{array}$ & $\begin{array}{c}12.1 \\
0\end{array}$ & $\begin{array}{l}16 \\
20\end{array}$ \\
\hline No. of cirri in right marginal row 1 & $\begin{array}{l}\text { Ko } \\
\text { Ch }\end{array}$ & $\begin{array}{l}16 \\
12\end{array}$ & $\begin{array}{l}29 \\
22\end{array}$ & $\begin{array}{l}23.5 \\
17.5\end{array}$ & $\begin{array}{l}3.76 \\
2.74\end{array}$ & $\begin{array}{l}16.0 \\
15.7\end{array}$ & $\begin{array}{l}16 \\
19\end{array}$ \\
\hline No. of cirri in right marginal row 2 & $\begin{array}{l}\text { Ko } \\
\text { Ch }\end{array}$ & $\begin{array}{l}21 \\
14\end{array}$ & $\begin{array}{l}34 \\
27\end{array}$ & $\begin{array}{l}26.4 \\
21.9\end{array}$ & $\begin{array}{l}3.16 \\
4.00\end{array}$ & $\begin{array}{l}12.0 \\
18.3\end{array}$ & $\begin{array}{l}16 \\
19\end{array}$ \\
\hline No. of cirri in right marginal row 3 & $\begin{array}{l}\text { Ko } \\
\text { Ch }\end{array}$ & $\begin{array}{l}20 \\
11\end{array}$ & $\begin{array}{l}34 \\
20\end{array}$ & $\begin{array}{l}26.6 \\
16.5\end{array}$ & $\begin{array}{l}4.18 \\
2.59\end{array}$ & $\begin{array}{l}15.7 \\
15.7\end{array}$ & $\begin{array}{l}16 \\
19\end{array}$ \\
\hline No. of cirri in right marginal row 4 & $\begin{array}{l}\text { Ko } \\
\text { Ch }\end{array}$ & $\begin{array}{c}16 \\
-\end{array}$ & $\begin{array}{c}35 \\
-\end{array}$ & $\begin{array}{r}23.5 \\
-\end{array}$ & $\begin{array}{r}5.00 \\
-\end{array}$ & $\begin{array}{r}21.2 \\
-\end{array}$ & $\begin{array}{c}15 \\
-\end{array}$ \\
\hline No. of cirri in right marginal row 5 & $\begin{array}{l}\text { Ko } \\
\text { Ch }\end{array}$ & $\begin{array}{r}22 \\
-\end{array}$ & $\begin{array}{c}32 \\
-\end{array}$ & $\begin{array}{r}26.0 \\
-\end{array}$ & $\begin{array}{r}5.29 \\
-\end{array}$ & $\begin{array}{r}20.4 \\
-\end{array}$ & $\begin{array}{l}3 \\
-\end{array}$ \\
\hline No. of dorsal kineties & $\begin{array}{l}\text { Ko } \\
\text { Ch }\end{array}$ & $\begin{array}{l}3 \\
3\end{array}$ & $\begin{array}{l}3 \\
3\end{array}$ & $\begin{array}{l}3.0 \\
3.0\end{array}$ & $\begin{array}{l}0 \\
0\end{array}$ & $\begin{array}{l}0 \\
0\end{array}$ & $\begin{array}{l}16 \\
17\end{array}$ \\
\hline No. of macronuclear nodules & $\begin{array}{l}\text { Ko } \\
\text { Ch }\end{array}$ & $\begin{array}{l}62 \\
50\end{array}$ & $\begin{array}{r}111 \\
71\end{array}$ & $\begin{array}{l}81.9 \\
61.4\end{array}$ & $\begin{array}{r}18.15 \\
6.71\end{array}$ & $\begin{array}{l}22.2 \\
10.9\end{array}$ & $\begin{array}{r}9 \\
16\end{array}$ \\
\hline
\end{tabular}

All data compared protargol-impregnated specimens of Korean population (Ko) and Chinese population (Ch).

$\mathrm{P}$, population; Min, minimum; Max, maximum; Mean, arithmetic mean; CV, coefficient of variation in \%; $n$, number of individuals examined. 
ording to the relativeness of both morphology and phylogeny (Berger, 2006; Gao et al., 2010; Yi and Song, 2011). Among ca. 40 species known from this genus, following five species showed closest relationship with Anteholosticha pulchra in morphology: A. gracilis, A. xanthichroma, A. australis, A. sigmoidea and $A$. monilata.

Anteholosticha gracilis is most similar to A. pulchra because both species have four frontal and two frontoterminal cirri as marine ciliates. However Anteholosticha pulchra differs from A. gracilis mainly in size (190-300 $\times 30-55 \mu \mathrm{m}$ vs. $100-150 \times 30-40 \mu \mathrm{m}$ in vivo), position of contractile vacuole (posterior $1 / 4$ vs. anterior 1/3), color of cortical granules (reddish vs. yellow-greenish), number of dorsal kineties (four vs. three), adoral membranelles (46-60 vs. 24-30) and pair of midventral cirri (27-34 vs. 17-24) (Hu and Suzuki, 2004). Anteholosticha pulchra can be distinguished from other species by the position of contractile vacuoles: it locates around 1/4 region from the posterior margin in A. pulchra; around $1 / 3$ from the anterior margin in A. gracilis; ahead of mid-body in A. xanthichroma, A. australis, A. sigmoidea and A. monilata (Foissner and Didier, 1981; Foissner, 1982; Wirnsberger and Foissner, 1987; Blatterer and Foissner, 1988; Hu and Suzuki, 2004).

Nothoholosticha fasciola transferred from the genus Anteholosticha by Li et al. (2009) because this species has no frontoterminal cirri. However two species are similar in following characteristics, e.g., one buccal cirrus and long beltlike body shape. However, A. pulchra differs from N. fasciola in having frontoterminal cirri (vs. absent), four frontal cirri (vs. six), four dorsal kineties (vs. three), reddish cortical granules (vs. bright orange) and the contractile vacuole position (located around 1/5 region from the posterior margin in N. fasciola) (Li et al., 2009).

The Korean population corresponds well with Chinese population reported by Li et al. (2007), and showed high similarity each other in morphometric characteristics (Table 1).

The SSU rDNA sequence of Korean A. pulchra is $1,650 \mathrm{bp}$ in length (GenBank accession no: JN880476). Inter-specific genetic variation among five species (A. pulchra, A. gracilis, A. monilata, A. pseudomonilata, and N. fasciola) are ranged from $3.3 \%$ to $6.6 \%$ (Table 3 ).

${ }^{1 * G e n u s ~ M e t a u r o s t y l o p s i s ~ S o n g, ~ P e t z ~ a n d ~ W a r r e n, ~} 2001$

2*Metaurostylopsis struederkypkeae Shao et al., 2008

(Table 2, Figs. 1F-L, 3)

Metaurostylopsis struederkypkeae Shao et al., 2008: 289, figs. 1-20.
Description. Live cell size usually $80-110 \times 40-50 \mu \mathrm{m}$ (Figs. $1 \mathrm{~F}, 3 \mathrm{~A}-\mathrm{C})$, slender in shape and slightly contractile, with anterior and posterior ends rounded, and contractile vacuole approximately $10 \mu \mathrm{m}$ in diameter located on left side of equatorial level of cell (Fig. 3C, arrow). Two types of cortical granules: one small and reddish, approximately $0.5 \mu \mathrm{m}$ across, spread irregularly on surface (Figs. 1G, H, 3D, arrowhead), and other one yellow-green, approximately $1.5 \mu \mathrm{m}$ across, situated at base of cirri, with some cortical granules clustered along cirral rows and dorsal kineties (Figs. 1G, H, 3D, arrow). Color of cells appeared reddish under low magnification due to numerous small cortical granules. Lengths of transverse and frontal cirri $15 \mu \mathrm{m}$ and $13 \mu \mathrm{m}$, respectively. Other somatic cirri, midventral, left and right marginal cirri, $c a .10 \mu \mathrm{m}$ in length. Four frontal cirri and four to eight frontoterminal cirri located near distal portion of adoral membranelles (Fig. $3 \mathrm{H}$, arrow). Two to six transverse cirri, and one buccal cirrus located in middle of next paroral membrane (Fig. 3H, arrowhead). Left and right marginal rows composed of five to seven and three to five, respectively (Fig. 3F). 12-20 midventral pairs, and six to nine unpaired midventral cirri between midventral pairs and transverse cirri, three dorsal kineties (Fig. 3G, arrows), and separately two dikinetids (Fig. 3G, arrowheads) on anterior dorsal side. Macronuclear nodules, ovoid and ellipsoid shape, $c a$. 82. Membranelles in adoral zone consisted of 25-36 membranelles, and portion of adoral zone is ca. $35-45 \%$ in length. Paroral and endoral membrane are equal level in length.

Distribution. China (Qingdao, the Yellow Sea) and Korea (this study).

Remarks. There are six species in this genus: Metaurostylopsis marina Song et al., 2001, M. rubra Song and Wilbert, 2002, M. songi Lei et al., 2005, M. salina Lei et al., 2005, $M$. struederkypkeae Shao et al., 2008, and M. cheni Chen et al., 2011.

Metaurostylopsis struederkypkeae and M. rubra have reddish cell color. However M. struederkypkeae is distinguished from $M$. rubra by the number of right marginal rows (3-5 vs. 6-7) and the type of cortical granules (two vs. one) and size $(80-110 \times 40-50 \mu \mathrm{m}$ vs. $150-300 \times 50-90 \mu \mathrm{m}$ in vivo) (Song and Wilbert, 2002). Metaurostylopsis struederkypkeae is distinguished from M. marina by the body shape (slender vs. oval), the cell color (reddish vs. colorless) and the type of cortical granules (two vs. one) (Song et al., 2001).

The Korean population of $M$. struederkypkeae corresponds with the original description by Shao et al. (2008) and morphometric comparisons highly overlap (Table 2); however, there are a few differences. The Korean population has more

Korean name: ${ }^{1 *}$ 사미주하모충 (신칭), ${ }^{2 *}$ 작은홍색사미주하모충 (신칭) 

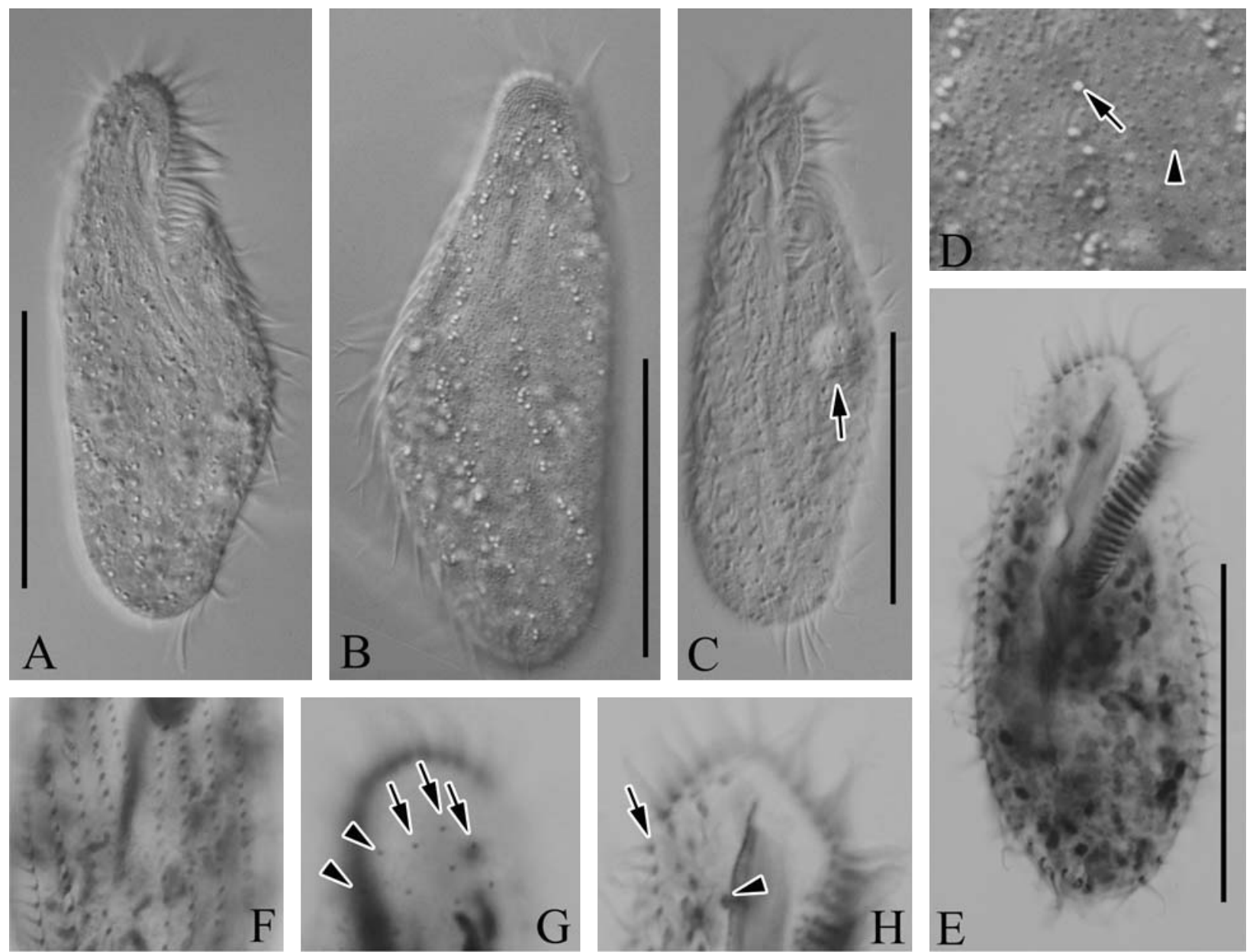

Fig. 3. Micrographs of Metaurostylopsis struederkypkeae from live (A-D) and protargol impregnated (E-H) specimen. A, B, Live ventral and dorsal views; C, Contractile vacuole (arrow); D, Yellow-green cortical granules (arrow), small reddish cortical granules (arrowhead); E, Ventral view of protargol-impregnated specimen; F, Ventral view, left and right marginal rows; G, Dorsal view, typically three dorsal kineties (arrows) and two dikinetids (arrowheads); H, Frontoterminal (arrow) and buccal (arrowhead) cirri. Scale bars: $\mathrm{A}-\mathrm{C}, \mathrm{E}=50 \mu \mathrm{m}$.

Table 3. Kimura two-parameter pairwise distances (\%) among the five species in Anteholosticha-Nothoholosticha assemblage based on small subunit ribosomal DNA sequences

\begin{tabular}{|c|c|c|c|c|c|}
\hline & A. pulchra & A. gracilis & A. monilata & A. pseudomonilata & N. fasciola \\
\hline A. pulchra (this study) & - & & & & \\
\hline A. gracilis (FJ775713) & 6.58 & - & & & \\
\hline A. monilata (GU942567) & 5.04 & 4.10 & - & & \\
\hline A. pseudomonilata (HM568416) & 3.96 & 5.19 & 3.29 & - & \\
\hline N. fasciola (FJ377548) & 3.62 & 6.72 & 5.18 & 3.89 & - \\
\hline
\end{tabular}

number of left and right marginal rows, midventral pairs, and macronuclear nodules than those of the Chinese population (Shao et al., 2008).

The SSU rDNA sequence of $M$. struederkypkeae is 1,652 bp in length (GenBank accession no: JN880477). The inter- specific pairwise distances between $M$. struederkypkeae and its relatives (M. cheni and M. salina) are more than $2 \%$, while intra-specific variation are less than $0.3 \%$ among two Korean and one Chinese M. struederkypkeae populations (Table 4). 
Table 4. Kimura two-parameter pairwise distance (\%) based on small subunit ribosomal DNA sequences

\begin{tabular}{|c|c|c|c|c|c|}
\hline & $\begin{array}{l}\text { Metaurostylopsis } \\
\text { struederkypkeae }\end{array}$ & M. struederkypkeae ${ }^{\mathrm{b}}$ & M. struederkypkeae ${ }^{c}$ & M. cheni & M. salina \\
\hline M. struederkypkeae (this study) & - & & & & \\
\hline M. struederkypkeae ${ }^{\mathrm{b}}$ (GU942568) & 0.18 & - & & & \\
\hline M. struederkypkeae (EU220228) & 0.12 & 0.30 & - & & \\
\hline M. cheni (HM623916) & 2.22 & 2.28 & 2.34 & - & \\
\hline M. salina (EU220229) & 2.22 & 2.28 & 2.34 & 0.61 & - \\
\hline
\end{tabular}

a Korean population from Youngrang lagoon (this study), b'Korean population from Taehwagang river (Li et al., 2011), 'Chinese population (Shao et al., 2008).

\section{ACKNOWLEDGMENTS}

This study was supported by the Invasive Species Management Program in Marine Ecosystem, Korean Ministry of Land, Transport \& Maritime Affairs of Korean Government, and also funded by the National Fisheries Research \& Development Institute (NFRDI) of Korea and Polar Academic Program (PAP), KOPRI.

\section{REFERENCES}

Berger H, 2001. Catalogue of ciliate names 1. Hypotrichs. Verlag Helmut Berger, Salzburg, pp. 1-206.

Berger H, 2003. Redefinition of Holosticha Wrzesniowski, 1877 (Ciliophora, Hypotricha). European Journal of Protistology, 39:373-379.

Berger H, 2006. Monograph of the Urostyloidea (Ciliophora, Hypotricha). Springer, Dordrecht, pp. 1-1304.

Blatterer H, Foissner W, 1988. Beitrag zur terricolen Ciliatenfauna (Protozoa: Ciliophora) Australiens. Stapfia, 17:1-84.

Borror AC, 1979. Redefinition of the Urostylidae (Ciliophora, Hypotrichida) on the basis of morphogenetic characters. The Journal of Eurkaryotic Microbiology, 26:544-550.

Borror AC, Wicklow BJ, 1983. The suborder Urostylina Jankowski (Ciliophora, Hypotrichida): morphology, systematics and identification of species. Acta Protozoologica, 22:97126.

Chen X, Huang J, Song W, 2011. Ontogeny and phylogeny of Metaurostylopsis cheni sp. n. (Protozoa, Ciliophora), with estimating the systematic position of Metaurostylopsis. Zoologica Scripta, 40:99-111.

Foissner W, 1982. Ecology and taxonomy of the hypotrichida (Protozoa: Ciliophora) of some Austrian soil. Archiv Für Protistenkunde, 126:19-143.

Foissner W, 1991. Basic light and scanning electron microscopic methods for taxonomic studies of ciliated protozoa. European Journal of Protistology, 27:313-330.

Foissner W, Didier P, 1981. Morphologie und infraciliatur einiger kinetofragminophorer und hypotricher ciliaten aus den Fliessgewässern von Besse-en-Chandesse (Frankreich). Annales de la Station limnologique de Besse, 15:254-275.
Gao F, Yi Z, Gong J, Al-Rasheid KAS, Song W, 2010. Molecular phylogeny and species separation of five morphologically similar Holosticha-complex ciliates (Protozoa, Ciliophora) using ARDRA riboprinting and multigene sequence data. Chinese Journal of Oceanology and Limnology, 28:542-548.

Hall TA, 1999. BioEdit: a user-friendly biological sequence alignment editor and analysis program for Windows 95/98/ NT. Nucleic Acids Symposium Series, 41:95-98.

Hu X, Suzuki T, 2004. A new species of Holosticha (Ciliophora: Hypotrichida) from the coastal waters of Nagasaki, Japan: Holosticha nagasakiensis sp. nov. Journal of the Marine Biological Association of the United Kingdom, 84:9-13.

Jung JH, Baek YS, Min GS, 2011. New record of two Apokeronopsis species (Ciliophora: Urostylida: Pseudokeronopsidae) from Korea. Korean Journal of Systematic Zoology, 27:115122.

Kahl A, 1932. Urtiere oder Protozoa I: Wimpertiere oder Ciliata (Infusoria), 3. Spirotricha. Die Tierwelt Deutschlands, 25: 399-650.

Kahl A, 1933. Ciliata libera et ectocommensalia. Tierwelt der Nord- und Ostsee, 23:29-146.

Kumar S, Tamura K, Nei M, 2004. MEGA3: Integrated software for molecular evolutionary genetics analysis and sequence alignment. Briefings in Bioinformatics, 5:150-163.

Li L, Khan SN, Ji D, Shin MK, Berger H, 2011. Morphology and small subunit (SSU) rRNA gene sequence of the new brackish water ciliate Neobakuella flava n. g., n. sp. (Ciliophora, Spirotricha, Bakuellidae) and SSU rRNA gene sequences of six additional hypotrichs from Korea. The Journal of Eukaryotic Microbiology, 58:339-351.

Li L, Song W, Hu X, 2007. Two marine hypotrichs from north China, with description of Spiroamphisiella hembergeri gen. nov., spec. nov. (Ciliophora, Hypotricha). Acta Protozoologica, 46:107-120.

Li L, Zhang Q, Hu X, Warren A, Al-Rasheid KAS, Al-Khedheiry AA, Song W, 2009. A redescription of the marine hypotrichous ciliate, Nothoholosticha fasciola (Kahl, 1932) nov gen., nov comb. (Ciliophora: Urostylida) with brief notes on its cellular reorganization and SS rRNA gene sequence. European Journal of Protistology, 45:237-248.

Lynn DH, 2008. The ciliated protozoa: characterization, classification, and guide to the literature. Springer, New York, pp. $1-605$. 
Shao C, Song W, Al-Rasheid KAS, Yi Z, Chen X, Al-Farraj SA, Al-Quraishy SA, 2008. Morphology and infraciliature of two new marine urostylid ciliates: Metaurostylopsis struederkypkeae n. sp. and Thigmokeronopsis stoecki n. sp. (Ciliophora, Hypotrichida) from China. The Journal of Eukaryotic Microbiology, 55:289-296.

Song W, Petz W, Warren A, 2001. Morphology and morphogenesis of the poorly-known marine urostylid ciliate, Metaurostylopsis marina (Kahl, 1932) nov. gen., nov. comb. (Protozoa, Ciliophora, Hypotrichida). European Journal of Protistology, 37:63-76.

Song W, Wilbert N, 2002. Faunistic studies on marine ciliates from the Antarctic benthic area, including descriptions of one epizoic form, 6 new species and, 2 new genera (Proto- zoa: Ciliophora). Acta Protozoologica, 41:23-61.

Wirnsberger E, Foissner W, 1987. Morphologie von Holosticha xanthichroma sp. $\mathrm{n}$. und die variabilität der infraciliatur in der gattung Holosticha (Ciliophora, Hypotrichida). Acta Protozoologica, 26:1-8.

Yi Z, Song W, 2011. Evolution of the order Urostylida (Protozoa, Ciliophora): new hypotheses based on multi-gene information and identification of localized incongruence. PLoS ONE, 6:e17471. 